\title{
Cytotoxic Screening of Some Tanzania Medicinal plants
}

\author{
M.J. MOSHI*1 ${ }^{\prime}$ A. KAMUHABWA ${ }^{2}$, Z. MBWAMBO' AND P. DE WITTE ${ }^{3}$
}

'Institute of Traditional Medicine, Muhumbili University College of Health Sciences, P.O. Box 38009, Dar es salaam, Tanzania.

${ }^{2}$ Department of Pharmacognosy, School of Pharmacy, Muhimbili University College of Health Sciences, Box 65001, Dar es Salaam, Tanzania.

${ }^{3}$ Laboratovium voor Farmaceutische Biologie en Fytofarmacologie, Faculteit Farmaceutische, Wetenschappen, Katholieke Universiteit Leuven, Van Evenstraat 4, B-3000 Leuven, Belgium.

Twenty plants that are used in traditional medicine in Iringa, Tanzania, were tested for in vitro cytotoxic activity on human bladder carcinoma (RT-4), colon adenocarcinoma (HT29), and skin carcinoma (A431) cell lines. At $100 \mu \mathrm{g} / \mathrm{ml}$ Albizia harveyi, Albizia anthelmintica, Dalbergia nitidula, Euphorbia grantii and Rauvolfia caffra reduced cell proliferation to $50 \%$ or more of the three cell lines. Albizia harveyi showed a significant cytotoxic activity on the RT-4 cell line (percentage survival $23 \%$ ) at $10 \mu \mathrm{g} / \mathrm{ml}$. It showed a weak cytotoxic activity on the HT-29 cell line. Dalbergia nitidula showed a weak cytotoxic activity with percentage death of the RT-4 and HT-29 cell lines of 39 and $34 \%$, respectively, at the $10 \mu \mathrm{g} / \mathrm{ml}$ level. These results show that $19(95 \%)$ of the plant extracts tested are non-toxic. One plant (5\%), Albizia harveyi showed cytotoxic activity on one of the cell lines used, which was in agreement with the accepted detection level of biological activity by chance. Bioassay guided fractionation of the plant extracts to identify active compound(s) is suggested.

Keywords: Cytotoxicity, human cancer cell lines, plant extracts

\section{INTRODUCTION}

Tanzania has a wealth of flora comprising over 10,000 plant species, of which 1122 are endemic $[1,2]$. Many of these plants are used as medicines by the rural populations [3]. It has also been reported that $21 \%$ of the people who utilize public health services in Dar es Salaam consult a traditional healer before doing so [4]. This finding indicates the popularity of traditional medicines and point to the possibility that some of these plants may indeed be effective, although most of them are yet to be exploited.

One of the ways in which these therapies could be identified and utilized is by conducting disease-related ethnobiomedical surveys. This is an interdisciplinary approach which involves the collaboration of medical doctors, ethnobotanists, indigenous healers and communities $[5,6,7]$. The establishment of such a team permits the physician to interact with the healers in evaluation of the clinical diagnosis, while at the same time the ethnobotanist can identify the plants being used as medicines [7]. The information collected can then be compared with that in literature to assist in developing a list of priority plants for both phytochemical and pharmacological studies.

In this study, twenty plants used by traditional healers in Iringa region (Tanzania), were evaluated for cytotoxic activity on three human cancer cell-lines.

\section{MATERIALS AND METHODS}

\section{Materials}

RT-4 (human bladder carcinoma), HT29 (human colon adenocarcinoma) and A431 (human skin carcinoma) cell lines were obtained from American Type Culture Collection (Rockville, MD, USA), 3-(4,5-dimethylthiazol2-yl)-2,5-diphenyl-tetrazolium bromide (MTT) was bought from Sigma (St. Louis, MO, USA), the cell culture media and ingredients and phosphate-buffered saline (PBS) were obtained from Gibco (Gibco BRL, Paisley, Scotland). Microtitre tissue culture plates were bought from Falcon (NJ, USA) and dimethylsulfoxide (DMSO) was obtained from Sigma (Poole, Dorset, England). 


\section{Collection of plant materials}

Plants used in this study identified by the voucher numbers are indicated in Tablel. They were collected by Mr. E.B. Mhoro, and their respective voucher specimens were deposited in the Herbarium of the Institute of Traditional Medicine, Muhimbili University College of Health Sciences, Dar es Salaam, Tanzania.

\section{Plant preparation}

The plant materials were dried in open air under the sun, ground into powders and then $50 \mathrm{~g}$ extracted with $20 \%$ aqueous ethanol. The extracts were dried by rotary evaporation and the remaining traces of water were removed by freeze-drying. The dry extracts, ranging from 0.5 to $1.0 \mathrm{~g} / 50 \mathrm{~g}$ of starting material were stored in plastic containers at $-20^{\circ} \mathrm{C}$, until needed for testing.

\section{Cell culture}

Human bladder carcinoma (RT-4), human colon adenocarcinoma (HT29), and human skin carcinoma (A431) cells were grown at $37{ }^{\circ} \mathrm{C}$ in humidified $5 \% \mathrm{CO}_{2}$ and $95 \%$ air atmosphere in Minimum Essential Medium (MEM) with Earle's Salt containing $2 \mathrm{mM}$ L-glutamine, 1\% antibiotic/antimycotic solution, $1 \%$ nonessential amino acids, $1 \%$ anti-PPLO agent, and $10 \%$ fetal calf serum.

\section{Antiproliferative assay}

Extracts were first dissolved in DMSO to make stock solutions and then diluted in culture medium to yield an extract solution with a final DMSO concentration of $0.1 \% \mathrm{v} / \mathrm{v}$. This concentration of DMSO did not affect cell viability. Cells were seeded onto 96-well microtitre tissue culture plates at $5 \times 10^{3}$ cells per well and incubated for $24 \mathrm{~h}$ at $37{ }^{\circ} \mathrm{C}$. The medium was replaced with fresh medium containing different concentrations of extracts $(100 \mu \mathrm{g} / \mathrm{ml}$ and $10 \mu \mathrm{g} / \mathrm{ml})$ or the vehicle. The cells were then incubated at $37{ }^{\circ} \mathrm{C}$ for $72 \mathrm{~h}$. Afterwards, the extract-containing medium was removed and cell proliferation was determined. Cell proliferation was determined by using the MTT dye reduction assay. MTT was dissolved in phosphate buffered saline (PBS, $0.01 \mathrm{M}$; pH 7.4) and added to the cells $(1 \mathrm{mg} / \mathrm{ml})$ and the plates were incubated at $37^{\circ} \mathrm{C}$ for $4 \mathrm{~h}$. MTT was carefully removed and the resulting formazan crystals were dissolved in DMSO and added onto the wells $(100 \mu \mathrm{l} /$ well). The plates were placed on a shaker for $2 \mathrm{~h}$ and then read on a microtitre plate reader (SLT, Salzburg, Austria) at $550 \mathrm{~nm}$. The results are expressed as percentage cell survival as compared to controls. All experiments were performed at least three times.

\section{RESULTS}

Table 1 shows the names of the twenty plants used, voucher numbers, the parts collected, and the ethnomedical claims for which they were collected. The ethnomedical uses included malaria (40\%), epilepsy $(40 \%)$, diabetes $(30 \%)$, bilharzia (25\%), hypertension (20\%), HIV (15\%), cancer $(15 \%)$, and skin diseases (15\%). Sixty percent $(60 \%)$ of the plants had more than one ethnomedical use. Three of the plants collected, Asparagus africanus, Cassia abbreviata and Ziziphus abbyssinica were claimed to be used for the treatment of cancer. Table 2 shows the effect of the plant extracts on cell lines. At $100 \mu \mathrm{g} / \mathrm{ml}$ Albizia harveyi, Albizia anthelmintica, Dalbergia nitidula, Euphorbia grantii and Rauvolfia caffra exhibited up to $50 \%$ cytotoxicity on the three cell lines. Only one plant, Albizia harveyi showed a significant cytotoxic activity on the RT-4 cell line (percentage survival $23 \%$ ) at $10 \mu \mathrm{g} / \mathrm{ml}$. The other plant which performed well at $10 \mu \mathrm{g} / \mathrm{ml}$ is Dalbergia nitidula, with 39 and $34 \%$ cytotoxicity on RT-4 and HT-29 cells, respectively.

\section{DISCUSSION}

Three of the plants in this study, Asparagus africanus, Cassia abbreviata and Ziziphus abbyssinica are used by the local communities in Iringa for the treatment of cancer, but they did not show activity on the three human cancer cell lines. Lannea stuhlmannii, which has similar claims [8], also gave negative results like two earlier studies, one using brine shrimps [9] and another using HeLa (cervical carcinoma cell line) and A431 cell lines [10]. Ximenia caffra and Cassia abbreviata have also been retested but, it seems the two plants growing in Iringa were not as active as was expected from the previous study [10]. Ximenia caffra was inactive on the 3 cell lines at 10 and $100 \mu \mathrm{g} / \mathrm{ml}$. The results for Ximenia caffra are 


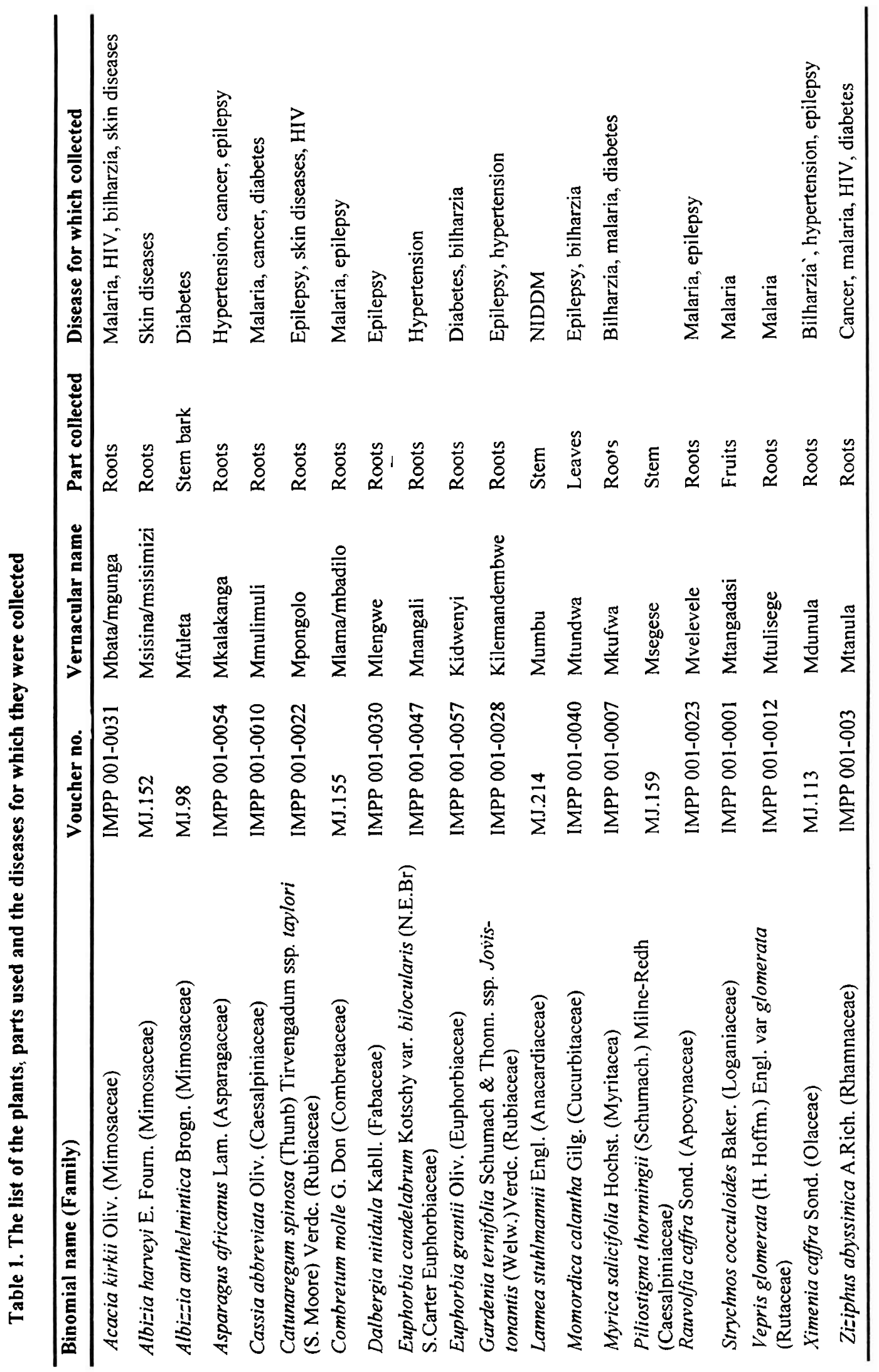


Table 2: Cytotoxicity (MTT) assay of plant extracts $(100$ and $10 \mu \mathrm{g} / \mathrm{ml})$ on human carcinoma cell lines (RT-4, HT-29 and A431). The results are expressed as percentage cell proliferation as compared to control cell lines. The results are an average of three independent experiments

\begin{tabular}{|c|c|c|c|c|c|c|}
\hline \multirow{2}{*}{$\begin{array}{l}20 \% \text { aqueous } \\
\text { ethanol extract of }\end{array}$} & \multicolumn{2}{|c|}{ RT-4 } & \multicolumn{2}{|c|}{ HT-29 } & \multicolumn{2}{|c|}{ A431 } \\
\hline & $100 \mu \mathrm{g} / \mathrm{ml}$ & $10 \mu \mathrm{g} / \mathrm{ml}$ & $100 \mu \mathrm{g} / \mathrm{ml}$ & $10 \mu \mathrm{g} / \mathrm{ml}$ & $100 \mu \mathrm{g} / \mathrm{ml}$ & $10 \mu \mathrm{g} / \mathrm{ml}$ \\
\hline Acacia kirkii & 79 & 87 & 89 & 95 & 67 & 92 \\
\hline Albizia harveyi & 21 & 23 & 58 & 69 & 75 & 87 \\
\hline Albizia anthelmintica & 55 & 97 & 36 & 91 & 8 & 106 \\
\hline Asparagus africanus & 100 & 88 & 57 & 86 & 63 & 83 \\
\hline Cassia abbreviata & 100 & 88 & 67 & 110 & 92 & 96 \\
\hline Catunaregum spinosa & 89 & 113 & 98 & 100 & 81 & 106 \\
\hline Combretum molle & 79 & 81 & 67 & 100 & 51 & 74 \\
\hline Dalbergia nitidula & 32 & 61 & 56 & 66 & 25 & 80 \\
\hline Euphorbia candelabrum & 100 & 76 & 94 & 84 & 71 & 71 \\
\hline Euphorbiagrantii & 31 & 100 & 51 & 86 & 21 & 100 \\
\hline Gardenia ternifolia & 100 & 94 & 96 & 100 & 98 & 102 \\
\hline Lannea stuhlmannii & 100 & 98 & 99 & 98 & 92 & 88 \\
\hline Momordica calantha & 100 & 100 & 32 & 100 & 47 & 90 \\
\hline Myrica salicifolia & 75 & 100 & 98 & 100 & 65 & 97 \\
\hline Piliostigma thonningii & 100 & 89 & 98 & 93 & 69 & 81 \\
\hline Rauvolfia caffra & 32 & 72 & 11 & 90 & 17 & 83 \\
\hline Strychnos cocculoides & 89 & 85 & 98 & 90 & 100 & 100 \\
\hline Vepris glomerata & 73 & 85 & 66 & 93 & 71 & 102 \\
\hline Ximenia caffra & 100 & 91 & 85 & 96 & 100 & 83 \\
\hline Ziziphus abyssinica & 100 & 88 & 88 & 98 & 69 & 102 \\
\hline
\end{tabular}

also in disagreement with a previous study which gave an $\mathrm{LC}_{50}$ of $0.7 \mu \mathrm{g} / \mathrm{ml}$ on brine shrimps [9]. Gardenia ternifolia [11,12], Mormodica calantha [13], Rauvolfia caffra [14], Dalbergia nitidula $[15,16]$, and Euphorbia candelabrum [13] are used for treatment of swellings, external tumors or for dressing wounds. At $10 \mu \mathrm{g} / \mathrm{ml}$ the only plant which inhibited cell proliferation by more than $50 \%$ was Albizia harveyi, while Euphorbia grantii, Dalbergia nitidula and Rauvolfia caffra showed reasonable inhibition at $100 \mu \mathrm{g} / \mathrm{ml}$.

\section{CONCLUSION}

The results show that $19(95 \%)$ of the plant extracts tested are non toxic. One plant $(5 \%)$, Albizia harveyi showed cytotoxic activity on one of the cell lines used, in agreement with the accepted detection level of biological activity by chance. Bioassay guided fractionation of the plant extracts to identify active compound(s) is suggested.

\section{ACKNOWLEDGEMENTS}

We are grateful to the NAPRALERT Data base of the University of Illinois, at Chicago for giving us access to literature and $\mathrm{Mr}$. E.B. Mhoro for identification and collection of plant material.

\section{REFERENCES}

[1] R.M. Polhill. Tanzania. In: I. Hedberg and $\mathrm{O}$. Hedberg (Eds), Conservation of vegetation in Africa South of the Sahara. Acta Phytogeographica Suecica. 54 (1968) 320.

[2] J.M.P. Brenan. Annals of the Missouri Botanical Garden 65 (1978) 437-478.

[3] C. Schlage. et al. Plant Biol. 2(2000) 83-92.

[4] P.M. Kilima, I. Ostermayer, M. Shija, M.M. Wolff and P.J. Evans. DUHP, Swiss Tropical Institute, Basel. 1993, p19.

[5] S.R. King and M.S. Tempesta. In: D.J. Chadwick, J. Marsh (eds). Ethnobotany and the search for new drugs. Ciba Fuundation Symposium 185. John 
Wiley and Sons chichester/NewYork (1994) pp 197-213.

[6] P. A. Cox and M. J. Balick. Scientific American June, (1994) pp 82-87.

[7] S.R. King and T. Carlson. The experience of Shaman Pharmaceuticals 1995.

[8] S.C. Chhabra R.L.A. Mahunnah and E.N. Mshiu. I. Pteridophytes and angiosperms (Acanthaceae to Canellaceae). J. Ethnopharmacol. 21 (1987) 253-277

[9] A.Y. Massele and C.M. Nshimo. E. Af.r Med. J. 72 (1995) 661-663.

[10] A. Kamuhabwa, C. Nshimo and P. de Witte. J. Ethnopharmacol. 70 (2000) 143-9.

[11] K.J. Achola, J.W. Mwangi and R.W. Munenge. Int. J. Pharmacog. 33 (1995) 250-252.
[12] S.C. Chhabra, R.L.A. Mahunnah and E.N.Mshiu. (Passifloraceae to Sapindaceae) J. Ethnopharmacol. 33 (1991) 143-157.

[13] I. Hedberg, O. Hedberg, P.J. Madati, K.E. Mshigeni, E.N. Mshiu and G. Samuelsson. J. Ethnopharmacol. 9 (1983) 105-127

[14] S.C. Chhabra and F.C. Uiso. Fitoterapia 62 (1991) 499-503.

[15] N.Z. Nyazema. Cent Afr. J. Med. 30 (1984) 80-83.

[16] F.R. Van Heerden, E.V. Brandt and D.G. Roux. J.Chem. Soc.Perkin Trans. I. 1978 (1978) 137-139.

[17] R.I. Geran, N.H. Greenberg, M.M. McDonald and B.J. Abbott. Cancer Chemotherapy Reports, Part 3, 3 (1972) 1-17. 